This item was submitted to Loughborough's Research Repository by the author.

Items in Figshare are protected by copyright, with all rights reserved, unless otherwise indicated.

\title{
Tax competition and the international distribution of firm ownership: an invariance result
}

\section{PLEASE CITE THE PUBLISHED VERSION}

http://dx.doi.org/10.1007/s10797-009-9126-z

\section{PUBLISHER}

(C) Springer

VERSION

AM (Accepted Manuscript)

\section{PUBLISHER STATEMENT}

This work is made available according to the conditions of the Creative Commons Attribution-NonCommercialNoDerivatives 4.0 International (CC BY-NC-ND 4.0) licence. Full details of this licence are available at: https://creativecommons.org/licenses/by-nc-nd/4.0/

\section{LICENCE}

CC BY-NC-ND 4.0

\section{REPOSITORY RECORD}

Ferrett, Benjamin E., and lan Wooton. 2019. "Tax Competition and the International Distribution of Firm Ownership: An Invariance Result”. figshare. https://hdl.handle.net/2134/23372. 
Revised version: February 2008

\title{
Tax Competition and the International Distribution of Firm Ownership:
}

\section{An Invariance Result}

\begin{abstract}
How does the international distribution of firm ownership affect the outcomes of tax/subsidy competition for mobile plants? As corporate ownership becomes increasingly globalised, this question becomes increasingly important for policy. We prove a strong Invariance Result in the context of the tax/subsidy competition between two host countries for a monopoly firm's plant. Both the equilibrium plant location and the equilibrium tax/subsidy offers are independent of the international distribution of the firm's ownership. The reason is that the tax/subsidy competition equalises the firm's post-tax profits across countries, making owners of capital indifferent towards the location of production.
\end{abstract}

Keywords: tax/subsidy competition; foreign direct investment; international distribution of firm ownership.

JEL classifications: F12, F23, H25, H73.

Corresponding author: Ben Ferrett, Department of Economics, Loughborough University, Loughborough, Leicestershire, LE11 3TU, United Kingdom. Email: b.e.ferrett@lboro.ac.uk.

Acknowledgements: The authors are grateful for comments from seminar participants at Nottingham University, the Spring 2006 MidWest Trade conference at MSU, ERWIT 2006 in Vienna, ETSG 2006 in Vienna, and the "Economic Geography and Fiscal Federalism" workshop in Dijon. Particular thanks are due to Tanguy van Ypersele, Jay Wilson, Pierre Picard, Yvon Rocaboy and three anonymous referees. Financial support from the Leverhulme Trust (programme grant F114/BF) is also gratefully acknowledged.

Ben Ferrett

Loughborough University and GEP, University of Nottingham

Ian Wooton

University of Strathclyde and CEPR 


\section{Introduction}

In many economic theory and policy contexts, we are accustomed to thinking of national governments as competing with tax and subsidy instruments to attract the production plants of "foreign" firms whose profits flow abroad. This assumption might be reasonable, for example, in the case of competition between European states for the investments of Japanese multinational enterprises (MNEs). However, in many cases (e.g., competition between EU member countries for the investments of European MNEs), substantial portions of the firms concerned are owned within the potential host countries themselves.

Increasing plant mobility has helped to undermine the traditional characterisation of tax/subsidy competition given above: national governments must now face the possibility that domestic firms will move production abroad if it is profitable to do so. Moreover, the globalisation of corporate ownership has made untenable the traditional assumption that firms labelled "foreign" due to their historical origins or the location of their headquarters will be entirely owned abroad. For example, the current significant scale of cross-border share ownership is illustrated in a recent study by the Federation of European Securities Exchanges (FESE, 2007): at the end of 2005, foreign investors accounted on average for one third of the value of European equities markets.

These observations on plant mobility and the globalisation of corporate ownership mean that the countries competing in fiscal inducements to attract mobile production plants frequently own substantial shares in the firms concerned. In such cases, benevolent governments will care about how tax/subsidy competition affects the profit income accruing to their own citizens. We examine the implications of this concern for both equilibrium tax/subsidy offers and plant locations, and we ask how a government's strategy to attract investment should change with the international distribution of the firm's ownership. The strong conclusion 
that we reach is that the strategy should be entirely independent of who owns the firm.

To illustrate some of the empirical issues involved, Table 1 below reports investment subsidies that the European Commission approved in the EU car industry over 2001-2004. The first point to note is that these subsidies generally appear large as a proportion of total investment, perhaps large enough to overturn the effects of corporate taxation on the projects concerned. This underlines the importance for countries of getting their corporate tax/subsidy policies right. Two further observations from the table challenge the traditional characterisation of tax/subsidy competition, which sees the target firms as being "foreign". First, national governments appear to pay subsidies to both domestic and foreign car companies. Thus, the UK government gave subsidies to firms based in several countries: Japanese Nissan, French Peugeot-Citroen as well as (ostensibly) British Vauxhall. ${ }^{1}$ Second, it is not the case that car firms receive higher subsidies abroad than they do in their home markets: the notionally German Volkswagen, for example, received a larger investment subsidy from Germany than from Spain. This means that the traditional characterisation of tax/subsidy competition as a contest for foreign firms is not even approximately correct.

It seems natural to expect that if the bidding countries own shares in the mobile firm, their setting of corporate taxes/subsidies will reflect a preference on the part of domestic capital owners for production to be located where operating profits are maximized. This intuition is, however, misleading. We show that the unique equilibrium of a tax/subsidy competition game between two governments to attract the plant of a firm is independent of how the firm's ownership is distributed internationally. This "Invariance Result" applies both to the equilibrium location of the firm's plant and to the countries' equilibrium tax/subsidy

\footnotetext{
${ }^{1}$ Indeed, it is unclear to what degree Vauxhall is British, being a subsidiary of General Motors. Given this lack of clarity about the nationality of firms, the question of whether ownership matters for policy becomes all the more important because, if it does, governments would need to invest in gathering the relevant ownership data.
} 
Table 1: Approved investment subsidies to car manufacturers in EU member states (2001-2004)

\begin{tabular}{|c|c|c|c|}
\hline Company & Host country & $\begin{array}{l}\text { State aid } \\
\left(\text { million } €^{a}\right)\end{array}$ & $\begin{array}{l}\text { Aid inten- } \\
\text { sity }(\%)^{b}\end{array}$ \\
\hline Nissan & U.K. & 60 & 18.6 \\
\hline Volkswagen & Germany & 75 & 12.3 \\
\hline Daimler Chrysler & Germany & 57 & 30.9 \\
\hline Renault & Spain & 18 & 14.3 \\
\hline Vauxhall & U.K. & 15 & 6.4 \\
\hline BMW & Germany & 363 & 30.1 \\
\hline BMW & Austria & 16 & 15.3 \\
\hline Volkswagen & Spain & 20 & 6.4 \\
\hline Peugeot Citroen & U.K. & 30 & 9.8 \\
\hline
\end{tabular}

${ }^{a} 1$ British Pound is converted to $1.5 €$

${ }^{b}$ Present value of state aid divided by present value of investment Source: Official Journal of the European Communities, C and L (http://eur-lex.europa.eu)

offers. Strikingly, it means that the nationality of the firm is irrelevant to the strategy that a potential host country should follow in offering investment incentives.

The remainder of the paper is organised as follows. In section 2 , we set up a model that focuses on the competition between two potential host countries for the plant of a monopoly firm. Our theoretical framework is deliberately simple with minimal structure in order to highlight the drivers of government/firm choices as clearly as possible. At the same time, however, our analysis is consistent with a very wide range of government motivations in tax/subsidy competition-for example, the employment/wage gains from inward foreign direct investment (FDI), technological spillovers to indigenous firms, tax revenue, profit income to capital owners, and consumer surplus.

In section 3, we establish what effect the international distribution of the MNE's ownership has on the equilibrium tax/subsidy offers made to the firm and its equilibrium plant location. We take the international distribution of the firm's ownership as exogenous, placing no restrictions as to how it is divided between the two bidding countries and the rest of the world. Given this, we derive our Invariance Result which shows that, under tax/subsidy 
competition, both the equilibrium plant location and tax/subsidy offers are independent of the international distribution of firm ownership.

In the conclusion, we present two important implications of our Invariance Result.

\section{A Model of Tax Competition}

We model the tax/subsidy competition between two host countries for the production plant of a monopoly firm. We want to investigate how the international distribution of the firm's ownership affects the countries' equilibrium tax/subsidy offers and the plant's equilibrium location. For this purpose, we partition the world into a region, which contains the potential host countries $A$ and $B$, and the rest of the world (RoW). If the MNE wishes to serve consumers in the region, it must invest in either $A$ or $B$ as we assume that trade costs between the region and RoW are prohibitive. In contrast, we make no specific assumptions (in terms of either levels or symmetry) about intra-regional trade costs between $A$ and $B$. For simplicity and in line with much of the existing literature, we rule out two-plant entry, where the firm sets up plants in both countries. However, as with Haufler and Wooton (1999), it would be straightforward to introduce explicitly into our analysis a plant fixed cost $F$ that is sufficiently large to rule out the choice of two plants in equilibrium.

Tax/subsidy competition is represented by a three-stage game of complete information. In stage one, countries $A$ and $B$ simultaneously and irreversibly post bids $B_{A}$ and $B_{B}$, respectively, which can be either taxes $(<0)$ or subsidies $(>0)$ and act as location-specific fixed costs. In stage two, the monopolist decides where to locate its plant, choosing between production in country $A$ or country $B$ or opting for $\varnothing$, where $\varnothing$ represents choosing not to invest in the region (and thereby not serving the regional market). Finally, the product markets in $A$ and $B$ are served in stage three. We solve the game backwards to isolate its subgame perfect Nash equilibrium in pure strategies. 


\subsection{Profits of the Firm}

We denote by $\Pi_{j}$ the firm's pre-tax profits on its operations within the region when its plant is located in country $j \in\{A, B\}$. If, for example, the firm chooses $A$, then it serves consumers in market $A$ with local production and those in market $B$ with exports. The $\Pi_{j}$ term comprises variable profits, earned on the basis of monopoly pricing in both countries, and any plant-specific fixed cost. However, as with trade costs, we place no restrictions on the firm's production costs in the two countries.

If the firm's cost structures are identical in $A$ and $B$ and if intra-regional trade is costless, then $\Pi_{A}=\Pi_{B}$. If trade is costly, this equality will not generally hold unless the countries' demand sides are also identical. Thus, for example, with identical cost structures and costly trade, we would have $\Pi_{A}>\Pi_{B}$ if $A$ 's market were larger than that of $B$. In order to avoid an extensive and unrewarding taxonomy, we assume

$$
\Pi_{A} \geq \Pi_{B} \geq 0
$$

There are two elements to this assumption. The first $\left(\Pi_{A}, \Pi_{B} \geq 0\right)$ is that the firm would find it profitable to set up in either country under laissez faire $\left(B_{A}=B_{B}=0\right)$. Thus, while the countries may choose to offer subsidies $\left(B_{A}, B_{B}>0\right)$ in order to attract the MNE's investment, these are not required to make local production profitable in absolute terms. Such subsidies would merely alter the relative profitability of alternative locations. Of course, the host countries may seek to tax the MNE's investment. We assume that such corporate taxes (represented by $B_{A}, B_{B}<0$ ) are source-based and that no double taxation of dividend income occurs in the capital owner's country of residence. ${ }^{2}$

The second element of assumption (1) is that country $A$ is, for whatever reason, the more profitable country in which to invest: $\Pi_{A} \geq \Pi_{B}$. This is innocuous and can be interpreted as

\footnotetext{
${ }^{2}$ See Keen (1993) for an empirical defence of the assumption of source-based coprate taxes.
} 


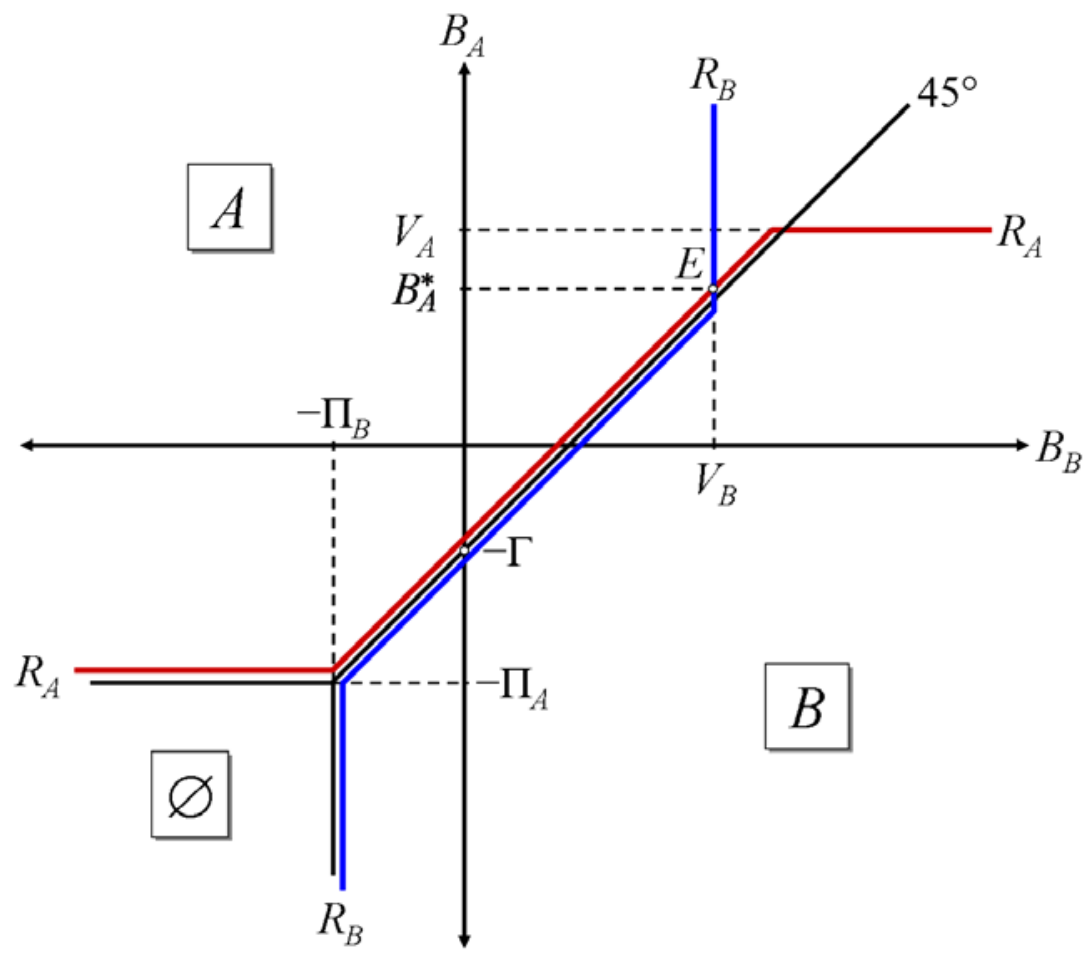

Figure 1: The Firm's Location Choice

a convention on how we label the host countries. Thus, in the absence of any inducements from the competing governments, the MNE will choose $A$ over $B$. Let $\Gamma=\Pi_{A}-\Pi_{B} \geq 0$, the international profit differential, be called country A's geographic advantage.

The firm chooses its location and prices to maximize post-tax profits, which constitute the aggregate income accruing to owners of capital. ${ }^{3}$ Post-tax profits $\Pi_{j}^{*}$ are given by

$$
\Pi_{j}^{*}=\left\{\begin{array}{l}
\Pi_{j}+B_{j} \text { if } j=A, B \\
0 \text { if } j=\varnothing
\end{array}\right.
$$

where $j \in\{A, B, \varnothing\}$ represents the firm's location choice.Figure 1 illustrates the firm's location choice when faced with different offers from the competing, potential-host nations. The bid space is divided into 3 regions. Region $\varnothing$ corresponds to the case where both

\footnotetext{
${ }^{3}$ It might be argued that a firm should maximize the utility of owners, rather than their income. When a firm has market power, these two do not necessarily coincide. Since profit maximization is simpler to analyse (it avoids the need to specify utility functions for owners), one could assume that capital owners' preferences are such that they choose not to consume the good in question.
} 
countries set such high taxes on the MNE that its after-tax profits would be negative in both $A$ and $B$, and it chooses not to invest (and receives zero profits). If $B_{A} \geq-\Pi_{A}$ and $B_{B} \geq-\Pi_{B}$, then the firm chooses between investing in $A$ and $B$, both of which offer positive post-tax profits. In the absence of offers from either government $\left(B_{A}=B_{B}=0\right)$, $A$ 's geographic advantage means that the firm will invest there. Otherwise, if $B$ 's financial inducement $B_{B}$ is sufficiently large to offset $A$ 's combined geographic advantage and its own offer $B_{A}$, then the firm will invest in $B$. Thus, $B$ wins the competition if $B_{B}-B_{A}>\Gamma$. Clearly, the MNE will be indifferent between locations $A$ and $B$ when post-tax profits are equalised, $\Pi_{A}^{*}=\Pi_{B}^{*}$, that is,

$$
\Gamma+B_{A}-B_{B}=0
$$

\subsection{Governments and Welfare}

We assume that the governments of countries $A$ and $B$ are benevolent, being motivated by national social welfare, and that they set their taxes/subsidies independently. The governments must balance their budgets and their only function is to redistribute income in a lump-sum manner between their citizens and the firm's owners. We further assume that the governments do not discriminate between domestic and foreign capital owners-for example, by imposing a withholding tax on outward profit flows. ${ }^{4}$

Corporate taxes in our model take the form of location-specific fixed costs, rather than proportional profits taxes. There are two justifications for this modelling choice. First, in reality, proportional profits taxes are typically set for the whole economy, rather than for specific industries. Our operating profit terms, $\Pi_{A}$ and $\Pi_{B}$, could be assumed to capture all economy-wide tax influences, which are exogenous to the particular industry in our model.

\footnotetext{
${ }^{4}$ In appendix 2, we extend our model to incorporate withholding taxes on the outward profit flows that accrue to foreign capital owners. We highlight circumstances where our central Invariance Result continues to hold.
} 
Second, we will show that corporate subsidies typically arise in our equilibrium and it seems natural to regard these as lump-sum-for example, as either direct cash payments to firms or the public provision of infrastructure at the plant.

We assume that the social welfare of country $i$ when the firm chooses plant location $j$ takes the following form:

$$
W_{i j}=\left\{\begin{array}{l}
e_{i} \Pi_{j}^{*}-B_{i}+S_{i j} \text { if } i=j \\
e_{i} \Pi_{j}^{*}+S_{i j} \text { if } i \neq j
\end{array}\right.
$$

where $i \in\{A, B\}$ and $j \in\{A, B, \varnothing\}$. The first term of (3) measures the income of capital owners in country $i$ from the profits of the MNE, where $e_{i}$ is the share of after-tax profits that are remitted to residents of country $i$. $B_{i}$ measures the cost to host country $i$ of its subsidy payments to the firm, paid only when the country is succesful in attracting the investment of the MNE. The final welfare term, $S_{i j}$, captures all other components of national social welfare.

The welfare function in (3) is intuitively appealing and, as we show in Appendix 1, it can be formally microfounded by invoking the widespread assumption of quasi-linear preferences. In these circumstances, $S_{i j}$ would constitute consumer surplus arising for citizens of country $i$ when the firm locates in country $j$.

\subsection{The Social Benefits of Investment}

For the sake of brevity, we focus on the following case, which appears to be the most empirically relevant, in solving the game:

$$
S_{i i} \geq S_{i j} \geq S_{i \varnothing} \text { for all } i, j \in\{A, B\}, i \neq j
$$

We are making two assumptions in (4). The first $\left(S_{i j} \geq S_{i \varnothing}\right)$ is that social benefits are created whenever the market is served, even if only by imports from the other country in 
the region. This reflects the notion that countries derive benefits (e.g., in terms of increased consumer surplus) whenever the product market is served, compared to the good being unavailable in the marketplace. Thus, even if the production takes place in another country, there are consumption benefits arising from importing the good. The second assumption in (4) is that local production of the good yields higher social benefits than imports $\left(S_{i i} \geq S_{i j}\right)$. This reflects what seems to be a widely-held government view. There are many possible reasons why, independently of capital income and tax/subsidy payments, host countries may favour local production, and our model's generality means that it is consistent with all of them. For example, there may be labour market benefits from inward FDI. MNEs may offer wage premia above workers' outside options, a polar case of which occurs when inward FDI relieves involuntary unemployment (Haaparanta, 1996 and Bjorvatn and Eckel, 2006). Alternatively, inward FDI may be associated with localized technological spillovers to indigenous firms (Fumagalli, 2003 and Olsen and Osmundsen, 2003). Finally, in the case where trade between $A$ and $B$ is costly, the market price will be lower, and consumer surplus higher, under local production, and benevolent governments will recognise this (Haufler and Wooton, 1999).

Of course, one can envisage factors that would tend to push $S_{i j}$ above $S_{i i}(i \neq j)$. Were there, for example, environmental pollution localized around the plant or if the other country offered lower variable production costs then this would favor foreign over local production. However, the fact that governments frequently offer inducements to inward FDI in practice suggests that such apparently perverse effects are, in general, not sufficiently strong as to overturn the ranking in (4). 


\section{The Role of Ownership}

We assume that the firm's ownership is distributed internationally in arbitrary proportions between $A, B$ and RoW and that the firm's post-tax profits are distributed internationally to its owners according to their ownership shares. Let equity shares $e_{A}$ and $e_{B}$ measure the proportions of the firm owned in countries $A$ and $B$, respectively. We take $e_{A}, e_{B}$ to be exogenous, and they must satisfy $e_{A}, e_{B} \geq 0$ and $e_{A}+e_{B} \leq 1$, where $1-e_{A}-e_{B}$ is the share of the firm owned in RoW. We now proceed to determine how the international pattern of firm ownership affects the offers made to the firm to induce it to invest and the firm's consequent choice of location in equilibrium.

In Figure $1, R_{A}$ and $R_{B}$ are the countries' best response functions in bid space. Since the two countries' decision problems are qualitatively identical, we focus for concreteness on the actions of country $A$, which owns a share $e_{A}$ of the firm. It is clear that if $A$ chooses to set a bid that attracts the firm, it will always set the lowest possible such bid. Therefore, $R_{A}$ will never lie above the lower boundary of the $A$ region in Figure 1.

If $B_{B}<-\Pi_{B}$, so that the firm prefers $\varnothing$ to $B$, then country $A$ when setting $B_{A}$ effectively chooses between plant locations $A$ and $\varnothing$. Under our assumptions (1) and (4), it is clear that country $A$ will choose to attract the firm with a bid of (just above) $-\Pi_{A}$ in this case. Local production generates both tax revenue and wider social benefits for $A$ over the $\varnothing$ outcome, while the firm's post-tax profits are pushed down to zero. Therefore, $R_{A}$ lies along the horizontal bottom border of the $A$ region in Figure 1 .

If $B_{B} \geq-\Pi_{B}$, then the firm locates in either $A$ or $B$ as locating in $B$ dominates $\varnothing$. If it hosts the firm, country $A$ 's social welfare is

$$
W_{A A}=e_{A}\left(\Pi_{A}+B_{A}\right)-B_{A}+S_{A A},
$$


while $A$ 's welfare if $B$ hosts the firm is

$$
W_{A B}=e_{A}\left(\Pi_{B}+B_{B}\right)+S_{A B}
$$

Consequently, $A$ 's welfare gain from local production compared to importing is

$$
W_{A A}-W_{A B}=e_{A}\left(\Gamma+B_{A}-B_{B}\right)-B_{A}+S_{A A}-S_{A B}
$$

This welfare change is just the sum of the changes in the income of $A$ 's capital owners, corporate tax revenue, and the welfare of the rest of society.

What is country $A$ 's valuation of the plant? In other words, what is the maximum that $A$ is willing to pay to attract local production? Assuming that $A$ behaves optimally, it will post the smallest bid necessary to attract the investment away from country $B$. Therefore, the MNE will be left essentially indifferent between locations. Consequently, (2) will hold, which reduces (5) to

$$
W_{A A}-W_{A B}=V_{A}-B_{A},
$$

where

$$
V_{A}=S_{A A}-S_{A B} \geq 0
$$

denotes A's valuation of the plant. Therefore, for any international distribution of ownership, country $A$ is willing to pay at most $V_{A}$ in subsidies to win the plant. Likewise, for any share $e_{B} \in\left[0,1-e_{A}\right]$ of the firm owned in $B$, country $B$ 's valuation is $V_{B}=S_{B B}-S_{B A} \geq 0$. Therefore, whenever government $A$ can attract the firm with a bid less than $V_{A}$, it does so. Otherwise, it sets $B_{A}=V_{A}$. This accounts for the kink in $R_{A}$ at $B_{A}=V_{A} \cdot{ }^{5}$

It follows from our construction of the $R_{A}$ function that there exists a unique perfect equilibrium along the 45-degree line in Figure 1 at point $E$. The identity of the winning

\footnotetext{
${ }^{5}$ We assume that the countries never post weakly dominated bids, which rules out all $B_{A}>V_{A}$ and $B_{B}>V_{B}$. All $B_{A}>V_{A}$ are weakly dominated by $B_{A}=V_{A}$. Pick any $B_{A}^{\prime}>V_{A}$. Then for all $B_{B}<B_{A}^{\prime}+\Gamma$, country $A^{\prime}$ 's welfare is strictly higher with $B_{A}=V_{A}$ (either $S_{A A}-V_{A}$ or $\left.S_{A B}\right)$ than with $B_{A}=B_{A}^{\prime}\left(S_{A A}-B_{A}^{\prime}\right)$. For all $B_{B}>B_{A}^{\prime}+\Gamma$, country $A$ is indifferent between $B_{A}=V_{A}, B_{A}^{\prime}$.
} 
country depends on whether

$$
V_{B}-V_{A} \gtrless \Gamma
$$

In other words, the firm's choice of investment location turns crucially upon whether $B$ 's valuation is sufficiently greater than $A$ 's to overcome the latter's geographic advantage. We shall refer to $V_{B}-V_{A}$ as the valuation premium that $B$ places on the firm.

In the perfect equilibrium, illustrated at point $E$ in Figure 1, country $A$ wins the plant. Country $B$ offers a subsidy equal to its valuation, $V_{B}$, and country $A$ 's winning bid, $B_{A}^{*}$, just exceeds $B$ 's subsidy less $A$ 's geographic advantage:

$$
B_{A}^{*}=V_{B}-\Gamma+\varepsilon
$$

Country A's winning bid of (8) therefore leaves the firm almost indifferent between the two production locations as post-tax profits are only infinitesimally higher if the firm locates in $A$.

The following Proposition characterises our game's perfect equilibrium:

Proposition: ( $i$ ) If pre-tax profits are equal in the two countries, $\Pi_{A}=\Pi_{B}$, then the country with the higher valuation wins the firm and pays a subsidy of just above the other country's valuation. (ii) If pre-tax profits are higher in $A$ than in $B, \Pi_{A}>\Pi_{B}$, then country $B$ wins the plant if and only if its valuation premium exceeds the geographic advantage offered by $A$.

When $\Pi_{A}=\Pi_{B}$, the tax/subsidy competition is a standard first-price auction. When $\Pi_{A}>\Pi_{B}$, as shown in Figure 1, the magnitude of country $A$ 's geographic advantage matters for the equilibrium. If the countries' bids are equal, then the firm will choose country $A$ because of its geographic advantage. Therefore, in order to win the bidding contest, country $A$ need not match $B$ 's bid. Indeed, $A$ can undercut $B$ by the exact amount of its geographic 
advantage and still leave the firm indifferent between locations. (If $\Gamma$ is sufficiently large, the possibility emerges that the monopolist could be taxed by $A$ in equilibrium.) Such a recognition by the bidding countries of the importance of geographic advantages underlies the result in part (ii). ${ }^{6}$

Because the countries' maximum bids, $V_{A}$ and $V_{B}$, are independent of national ownership shares, it follows immediately that the countries' best response functions $R_{A}$ and $R_{B}$, and consequently the equilibrium point $E$, are all independent of $e_{A}$ and $e_{B}$. This establishes our central result:

Invariance Result: The equilibrium plant location and tax/subsidy offers are independent of the international distribution of firm ownership.

This Invariance Result is striking in its simplicity and is also very strong. Perhaps the most remarkable implication is that the equilibrium with an arbitrary international distribution of ownership is identical to that under the special case of extra-regional firm ownership $\left(e_{A}=e_{B}=0\right)$, which has been extensively analysed in the literature (e.g., Haufler and Wooton, 1999). ${ }^{7}$ Thus the outcome of tax competition for a footloose production plant will be the same, regardless of who owns the firm.

The intuition behind the Invariance Result runs as follows. When considering whether to entice the firm away from its rival, a country has to determine at what point, as the rival country posts higher bids, trumping the rival's bid (that is, only just improving on the

\footnotetext{
${ }^{6}$ It is worth briefly highlighting that there are obvious circumstances where one country would possess both a valuation premium and a geographic advantage. For example, consider the case where the countries' fixed/variable cost structures are identical but trade is costly and country $A$ contains more identical households than $B$. Here $\Pi_{A}>\Pi_{B}$ due to $A$ 's larger market. However, we would also expect $V_{A}>V_{B}$ because the aggregate benefits from inward FDI to both workers (e.g., wage premia) and indigenous firms (e.g., technological spillovers) will be greater in the larger market, where the MNE will employ more workers and where (reasonably) there will be more indigenous firms to benefit from non-rivalrous spillovers. This is the specific case illustrated in Figure 1.

${ }^{7}$ To see this, substitute $e_{A}=0$ into (3) to give $W_{A A}=S_{A A}-B_{A}$ and $W_{A B}=S_{A B}$. In this case, $A$ 's reservation price is clearly $V_{A}$.
} 
rival's offer) is no longer worthwhile. As trumping leaves the firm with essentially identical after-tax profits from producing in either location, a country's capital owners are indifferent to it. Therefore, any gain in welfare from local production must originate from the rest of society and this remains the same whoever owns the firm.

At first glance the Invariance Result seems counter-intuitive. For example, assume that $\Pi_{A}>\Pi_{B}$. In this case, a sensible prior would seem to be that increasing $e_{A}$ should increase $A$ 's valuation of the plant, because the income of capital owners in $A$ would be highest under local production in the more profitable location. This intuition is false because it links capital income directly to pre-tax profits, $\Pi_{A}$ and $\Pi_{B}$, whereas the owners of capital derive income from the firm's post-tax profits, $\Pi_{A}^{*}$ and $\Pi_{B}^{*}$, which are endogenously determined and equal across the two countries in equilibrium. The tax/subsidy competition equalises post-tax profits across countries because the winning country never pays more for the plant than it has to. This makes owners of capital indifferent to the location of production and means that income from capital falls out of the countries' welfare comparisons between local and foreign production. ${ }^{8}$

We end this section by briefly discussing the key assumptions behind our Invariance Result. Our social welfare function, $W_{i j}$, is additively separable and linear in post-tax capital income, social benefits, and tax/subsidy payments. In Appendix 1, we provide explicit microfoundations for $W_{i j}$, taking preferences and technology as primitives adopting a quasilinear and quadratic household utility function that is widely used in the related literature. Additive separability is important for the Invariance Result because it allows us to cancel the capital-income terms in (5). However, it is not strictly necessary for $W_{i j}$ to be linear

\footnotetext{
${ }^{8}$ It might be thought that in the $e_{A}=1$ case, country $A$ would be indifferent between all $B_{A}$ because any subsidy payment is recycled entirely to domestic capital owners. However, this is false. If, for example, $B_{B}$ were extremely large, then $A$ would prefer to lose the contest as this outcome would yield huge overseas profit income for its citizens.
} 
in its three arguments. ${ }^{9} \quad$ The Invariance Result would continue to hold with, for example, a diminishing marginal utility of capital income and an increasing marginal cost of public funds. To incorporate these extensions, we would rewrite (3) as

$$
W_{i j}=\left\{\begin{array}{l}
u\left(e_{i} \Pi_{j}^{*}\right)-c\left(B_{i}\right)+S_{i j} \text { if } i=j \\
u\left(e_{i} \Pi_{j}^{*}\right)+S_{i j} \text { if } i \neq j
\end{array}\right.
$$

where $u^{\prime}(\cdot), c^{\prime}(\cdot)>0$ and $c^{\prime \prime}(\cdot)>0>u^{\prime \prime}(\cdot)$. In this case, it is straightforward to show that country $i$ would be prepared to pay at most $c^{-1}\left(V_{i}\right)$ in subsidies for the plant. Moreover, if $c^{\prime}(0)=1$, such that the marginal cost of public funds progressively rises from unity, then country $i$ 's reservation price is strictly less than $V_{i}$.

Another prominent assumption is that of monopoly. In practice, firms tend to face rivals on the product market. Our model could easily be extended to oligopoly by assuming that tax/subsidy-setting discriminates between rival firms and that we are analysing the contest for a single firm's plant within an oligopolistic industry. In such a case, the profit income from rival firms in the same industry would flow into our $S_{i j}$ terms. Our Invariance Result would then state that the equilibrium of the bidding contest for any given firm is independent of that particular firm's ownership distribution.

\section{Conclusion}

The key contribution of this paper is our Invariance Result, which states that the equilibrium of the tax/subsidy competition between two countries for a monopoly firm's plant is, in all respects, independent of how the firm's ownership is distributed internationally.

We close by pointing out two implications of our Invariance Result. The first concerns its relation to debates on the informational requirements for optimal policy choices. If a coun-

\footnotetext{
${ }^{9}$ Nor, in the case where $W$ is linear, do we need the weights on its three arguments to be equal. For example, our results would be unaffected if the governments placed a greater weight on profit income than on other components of social welfare.
} 
try's reservation price for a plant is independent of how the firm's ownership is distributed internationally, then it follows directly that a country does not need to know the international distribution of ownership to work out its reservation price. Therefore, our Invariance Result shows that optimal behaviour in tax/subsidy competition is possible without any knowledge of how firm ownership is distributed-information that is generally very hard to obtain. A further policy implication is that the recent concern, expressed by both the OECD (1998) and the EU (European Commission, 1998), that foreign firms tend to receive preferential tax treatment because they are foreign may be misplaced.

Secondly, our Invariance Result suggests that tax/subsidy competition for its plants should not play a role in explaining the international distribution of a firm's ownership, which our analysis takes as exogenous. For example, if firm owners gained much more from tax/subsidy competition under some international ownership distributions than others, then one could reasonably expect the "best" distributions to tend to arise in capital market equilibrium. However, our Invariance Result renders such a selection between ownership distributions impossible.

\section{References}

Bjorvatn, Kjetil and Carsten Eckel (2006), "Policy Competition for Foreign Direct Investment between Asymmetric Countries." European Economic Review 50, 18911907.

European Commission (1998), "Conclusions of the ECOFIN Council Meeting on 1 December 1997 Concerning Taxation Policy." Official Journal of the European Communities C2, 6/1/98, 1-6.

FESE (2007), "Share Ownership Structure in Europe." Report prepared for the Federation of European Securities Exchanges, available at www.fese.be/en.

Fumagalli, Chiara (2003), "On the Welfare Effects of Competition for Foreign Direct Investments." European Economic Review 47, 963-983.

Haaparanta, Pertti (1996). "Competition for Foreign Direct Investments." Journal of Public Economics 63, 141-153. 
Haufler, Andreas, and Ian Wooton (1999), "Country Size and Tax Competition for Foreign Direct Investment." Journal of Public Economics 71, 121-139.

Keen, Michael (1993), "The Welfare Economics of Tax Co-ordination in the European Community: A Survey." Fiscal Studies 14, 15-36.

OECD (1998). Harmful Tax Competition: An Emerging Global Issue. Paris: Organisation for Economic Co-operation and Development.

Olsen, Trond E., and Petter Osmundsen (2003). "Spillovers and International Competition for Investments." Journal of International Economics 59, 211-238.

Ottaviano, Gianmarco I. P., and Tanguy van Ypersele (2005). "Market Size and Tax Competition." Journal of International Economics 67, 25-46.

\section{Appendix 1: Derivation of the Social Welfare Function, $W_{i j}$}

In this appendix, we provide explicit microfoundations for the social welfare function, $W_{i j}$, that we use in the main text and for the interpretation of $S_{i j}$ as a measure of consumer surplus. The host-country economies, $A$ and $B$, have the following familiar structure (also used, for example, by Haufler and Wooton, 1999; and Ottaviano and van Ypersele, 2005, amongst many others). Both countries contain two sectors: $X$, the industry under analysis, and $Y$, which produces a numeraire good using only labour under perfect competition and constant returns to scale. Therefore, the real wage equals labour productivity in $Y, y$. Total post-tax household income in country $i$ equals $y-B_{i}+e_{i} \Pi_{j}^{*}$, where the firm chooses location $j$ and $B_{i}$ represents lump-sum taxes (this expression normalises the number of workers to 1 ).

The household maximizes the quasi-linear quadratic utility $U=\alpha X-0.5 X^{2}+Y$ subject to the budget constraint $y-B_{i}+e_{i} \Pi_{j}^{*} \geq p_{X} X+Y$, which binds in equilibrium because the marginal utility of $Y$ is 1 . In consumer equilibrium (with sufficiently high post-tax income so that $Y>0), X=\alpha-p_{X}$ and

$$
U=0.5\left(\alpha-p_{X}\right)^{2}+y-B_{i}+e_{i} \Pi_{j}^{*}
$$

where the first term on the R.H.S. is consumer surplus in market $X$. The above expression takes the form of the social welfare function $W_{i j}$ in the main text with $S_{i j}=0.5\left(\alpha-p_{X}\right)^{2}+y$ 
as a measure of consumer surplus. (Of course, when changes in utility are considered, the real wage $y$ drops out, so changes in $S$ are driven solely by changes in consumer surplus).

\section{Appendix 2: Equilibrium with Withholding Taxes}

Our main analysis assumed that corporate taxes/subsidies were applied to the firm's total operating profits at source, following which profit income was distributed to the firm's owners without further taxation (either in the host country or in the owners' home countries). However, in reality, countries sometimes impose withholding taxes on the outward profit flows that accrue to foreign capital owners. In this appendix, we examine how the imposition of withholding taxes affects our equilibrium.

Assume that both countries apply proportional withholding taxes to outward flows of profit income to the firm's foreign owners. Denote the withholding tax rates by $t_{A}$ and $t_{B}$, and assume that they are set for the whole economy and so are exogenous to our partial equilibrium analysis.

We get revised expressions for social welfare in country A:

$$
\begin{aligned}
& W_{A A}=e_{A} \Pi_{A}^{*}+S_{A A}-B_{A}+t_{A}\left(1-e_{A}\right) \Pi_{A}^{*} \\
& W_{A B}=e_{A}\left(1-t_{B}\right) \Pi_{B}^{*}+S_{A B}
\end{aligned}
$$

We can now derive country $A$ 's valuation of the firm in the presence of withholding taxes. Country $A$ prefers winning the firm if and only if $W_{A A} \geq W_{A B}$, i.e. iff

$$
e_{A} \Pi_{A}^{*}+S_{A A}-B_{A}+t_{A}\left(1-e_{A}\right) \Pi_{A}^{*} \geq e_{A}\left(1-t_{B}\right) \Pi_{B}^{*}+S_{A B}
$$

which can be rearranged to give

$$
S_{A A}-S_{A B}+e_{A}\left(1-t_{A}\right) \Pi_{A}^{*}+t_{A} \Pi_{A}^{*}-e_{A}\left(1-t_{B}\right) \Pi_{B}^{*} \geq B_{A}
$$

The question now arises: What measures of profit income does the tax/subsidy competition between countries $A$ and $B$ equalise? The fact that, in the absence of withholding taxes, 
tax/subsidy competition equalises the firm's post-tax profits across the two countries - to make the firm's owners indifferent between locations - is the key to our Invariance Result in the main text. However, with withholding taxes, the plant-location preferences of the firm's owners will differ depending on where they live - i.e., for given tax/subsidy levels, there will not typically be unanimity amongst the firm's owners about the optimal plant location. This consideration clearly complicates the analysis of equilibrium under withholding taxes. For simplicity, we introduce the notion of a decisive set of owners: a subset of the firm's owners is decisive if they can collectively determine the firm's choices. Moreover, for brevity, we restrict attention to the three cases where the firm has a decisive group of owners in one of $\{A, B, R o W\}$ since, in these three cases, the firm's responses to given values of the policy parameters are clear.

If owners in $R o W$ are decisive, then the firm will locate its plant in the country that offers the higher level of post-withholding-tax profits, $\left(1-t_{j}\right) \Pi_{j}^{*}$. Therefore, the industry-specific policy variables $B_{A}$ and $B_{B}$ will optimally be set so that $\left(1-t_{A}\right) \Pi_{A}^{*}=\left(1-t_{B}\right) \Pi_{B}^{*}$, and condition (10) becomes

$$
S_{A A}-S_{A B}+t_{A} \Pi_{A}^{*} \geq B_{A}
$$

The LHS of this condition gives $A$ 's valuation of the firm, and it is independent of the national ownership shares, $e_{A}$ and $e_{B}$. Therefore, if owners in RoW are decisive, then our Invariance Result continues to hold in the presence of withholding taxes - in the sense that equilibrium choices are independent of the international distribution of the firm's ownership. (Note, however, that because country $A$ retains withholding tax revenue when it hosts the plant, its valuation of the plant rises in the presence of withholding taxes.)

If owners in $A$ are decisive, then the tax/subsidy competition will make them indifferent between the two locations and set $e_{A} \Pi_{A}^{*}=e_{A}\left(1-t_{B}\right) \Pi_{B}^{*}$. Using this equality to simplify 
(10), it is straightforward to show that $A$ 's valuation of the plant then depends negatively on $e_{A}$ because $A$ 's withholding tax revenue falls as $e_{A}$ rises. If owners in $B$ are decisive so $e_{B} \Pi_{B}^{*}=e_{B}\left(1-t_{A}\right) \Pi_{A}^{*}$ in equilibrium, then no immediate simplification of (10) is possible. Therefore, with decisive owners in either $A$ or $B$, the countries' valuations, and hence also the equilibrium, typically depend on the national ownership shares. 